\title{
POTENTIAL FOR PHOTOVOLTAIC CELL MATERIAL BY GREEN SYNTHESIS OF SILICON CARBIDE FROM CORN COB THROUGH MAGNESIOTHERMIC REDUCTION
}

\author{
ARWIL NATHANIEL R. ALFONSO, JOEL R. SALAZAR, JUVY J. MONSERATE \& \\ MARILOU M. SARONG \\ Central Luzon State University, Philippines
}

\begin{abstract}
Corn cobs can be processed chemically to generate new products for electricity employing a simple, low-cost, and environment friendly method. In this article, silicon carbide ( $\mathrm{SiC})$ and activated carbon can be synthesized from corn cobs via sol-gel and a chemical activation method, respectively. SiC was synthesized by reacting the synthesized silica and activated carbon with magnesium powder, which served as catalyst at $600{ }^{\circ} \mathrm{C}$. The $\mathrm{SiC}$ was doped with varying amount of $\mathrm{Al}_{2} \mathrm{O}_{3}(0.01,0.015,0.02$ and $0.1 \mathrm{~g}$ ), a p-type dopant, via solvothermal synthesis. The undoped $\mathrm{SiC}$ was characterized using Scanning Electron Microscopy with Energy Dispersive X-ray Spectroscopy (SEM-EDX) and Fourier Transform Infrared (FTIR). Then, the band-gap energy and conductivity of undoped $\mathrm{SiC}$ and p-doped $\mathrm{SiC}$ were determined. SEM-EDX and FTIR analysis confirmed the presence of $\mathrm{Si}-\mathrm{C}$ bond in the synthesized $\mathrm{SiC}$ from corn cob. It was observed that $\mathrm{p}$-doped $\mathrm{SiC}$ absorbs higher energy in the visible region than undoped SiC. FTIR analysis confirmed the incorporation of the aluminum in the SiC. UV-vis spectroscopy confirmed that the synthesized p-doped $\mathrm{SiC}$ exhibits higher absorbance compared with undoped $\mathrm{SiC}$. Aluminum doping also increased absorption bands on the visible region making it more efficient for potential application in photovoltaic (solar) cells because of the decreased band-gap energy and increase in conductivity of p-doped $\mathrm{SiC}$. The ratio of 1:1-2 ( $\mathrm{SiC}: \mathrm{Al}$ ) showed the lowest band-gap and highest conductivity with a value of $1.57-1.58 \mathrm{eV}$ and $0.080-0.082 \mathrm{mS} / \mathrm{cm}$ compared with the amount of other p-dopants. Statistically, it was found that the 1:1-2 ratio of SiC:Al can be an effective p-junction for the application in photovoltaic (solar) cells.

Keywords: corn cob, p-doped $\mathrm{SiC}$, photovoltaic solar cell, silicon carbide $(\mathrm{SiC})$.
\end{abstract}

\section{INTRODUCTION}

Corn is second to rice as the most important crop in the Philippines, with one-third of Filipino farmers depending on corn as their source of livelihood. Corn production in the Philippines as of May 2018 is 2.48 metric tons, which is by $4.66 \%$ higher than the production in 2017 [1]. Corn cob (long, hard, and center part of the corn) is an agricultural waste commonly burnt and/or discarded, which leads to greenhouse gas releases, such as carbon dioxide [2]. Burning of agricultural waste is not only considered an economic loss but it also has harmful effects on the environment. Due to its huge availability as a raw material, utilizing corn cob waste as resource could become more economical in preparing activated carbon and silica; this will decrease the waste disposal and also convert corn cob into value-added products [3].

As a renewable raw material, corn cobs from grain maize have potential for the production of activated carbon [4] and silicon dioxide [3] - which are the raw materials for the synthesis of silicon carbide ( $\mathrm{SiC}$ ) [5] for potential application in photovoltaic solar cells.

$\mathrm{SiC}$ is a hard and strong semiconductor, which is the only chemical compound of carbon and silicon. It is composed of tetrahedrals of carbon and silicon atoms with strong bonds in the crystal lattice. This produces a very hard and strong material [6]. The most common process to obtain $\mathrm{SiC}$ needs high temperatures ranging from 1150 to $1500{ }^{\circ} \mathrm{C}$, thus requiring high 
energy [7]. Solvothermal synthesis is a method that utilizes low temperature $\left(600{ }^{0} \mathrm{C}\right)$ to synthesize $\mathrm{p}$-doped and $\mathrm{n}$-doped semiconductor (i.e. SiC) for $\mathrm{p}-\mathrm{n}$ junction in photovoltaic solar cells [8]. This method is simple, low-cost, and environment friendly.

A band-gap is the distance between the valence band of electrons and the conduction band. Essentially, the band-gap represents the minimum energy that is required to excite an electron up to a state in the conduction band where it can participate in conduction. The lower energy level is the valence band, and thus, if a gap exists between this level and band-gap, this allows one to visualize the difference between conductors, semiconductors, and insulators. Semiconductors are solids, which exhibit a weak electrical conductivity, which is proportional to the temperature. These materials have energy band structures that are similar to insulators except the energy gap is small enough so that it can be bridged by the Sun in photovoltaic cells [9].

In this study, nanocrystalline $\mathrm{SiC}$ material was synthesized. $\mathrm{SiC}$ and $\mathrm{p}$-doped $\mathrm{SiC}$ were synthesized and their performance (band-gap and conductivity) assessed for the potential application in photovoltaic solar cells.

\section{METHODS AND MATERIALS}

The procedure followed in this experimental investigation is summarized in the flowchart of Fig. 1.

\subsection{Materials}

Corncobs from yellow corn were collected from the local market of Talavera. Analytical grade of sodium hydroxide $(\mathrm{NaOH})$ pellets, sulfuric acid $\left(\mathrm{H}_{2} \mathrm{SO}_{4}\right)$, magnesium powder, and deionized water were used in the experiment for the synthesis of SiC. Aluminum oxide $\left(\mathrm{Al}_{2} \mathrm{O}_{3}\right)$ was used as a p-type dopant of $\mathrm{SiC}$.

\subsection{Synthesis of silica carbide from corn cob}

Grounded corn cobs were pyrolyzed at $600{ }^{\circ} \mathrm{C}$ to obtain corn cob ash (CCA). A $10 \mathrm{~g}$ of CCA was dissolved in $60 \mathrm{~mL}$ of $2.5 \mathrm{M} \mathrm{NaOH}$ and refluxed at $80^{\circ} \mathrm{C}$ for $3 \mathrm{~h}$. The $\mathrm{pH}$ of the cooled solution was adjusted to 7.0 with $2.5 \mathrm{M} \mathrm{H}_{2} \mathrm{SO}_{4}$ to form silica hydrogel and incubated for 12 $\mathrm{h}$. The gel was centrifuged at 4,000 rpm for $5 \mathrm{~min}$. The supernatant was discarded and the obtained silica was washed with deionized water and oven-dried at $80^{\circ} \mathrm{C}$ (Fig. 2).

\subsection{Synthesis of activated carbon powder from corn cob}

Grounded corn cobs were pyrolyzed at $600{ }^{\circ} \mathrm{C}$ for $30 \mathrm{~min}$ to obtain carbonized corn cob (CCC). A $20 \mathrm{~g}$ of CCC was dissolved in $60 \mathrm{~mL}$ of $2.5 \mathrm{M} \mathrm{NaOH}$ and refluxed at $120^{\circ} \mathrm{C}$ for 3 h. After cooling, the solution was filtered to obtain the solid carbon and oven-dried at $80^{\circ} \mathrm{C}$. The dried carbon was pyrolyzed at $900{ }^{\circ} \mathrm{C}$ for $1 \mathrm{~h}$ and was cooled overnight.

\subsection{Synthesis of $\mathrm{SiC}$}

$\mathrm{SiC}$ synthesis was based primarily on the solid-state method described by Dasog et al. [10]. A mixture of silica, activated carbon, and magnesium powder with a ratio of 1:0.2:0.88 (silica:activated carbon:magnesium) was transferred to a crucible. The mixture was pyrolyzed at 


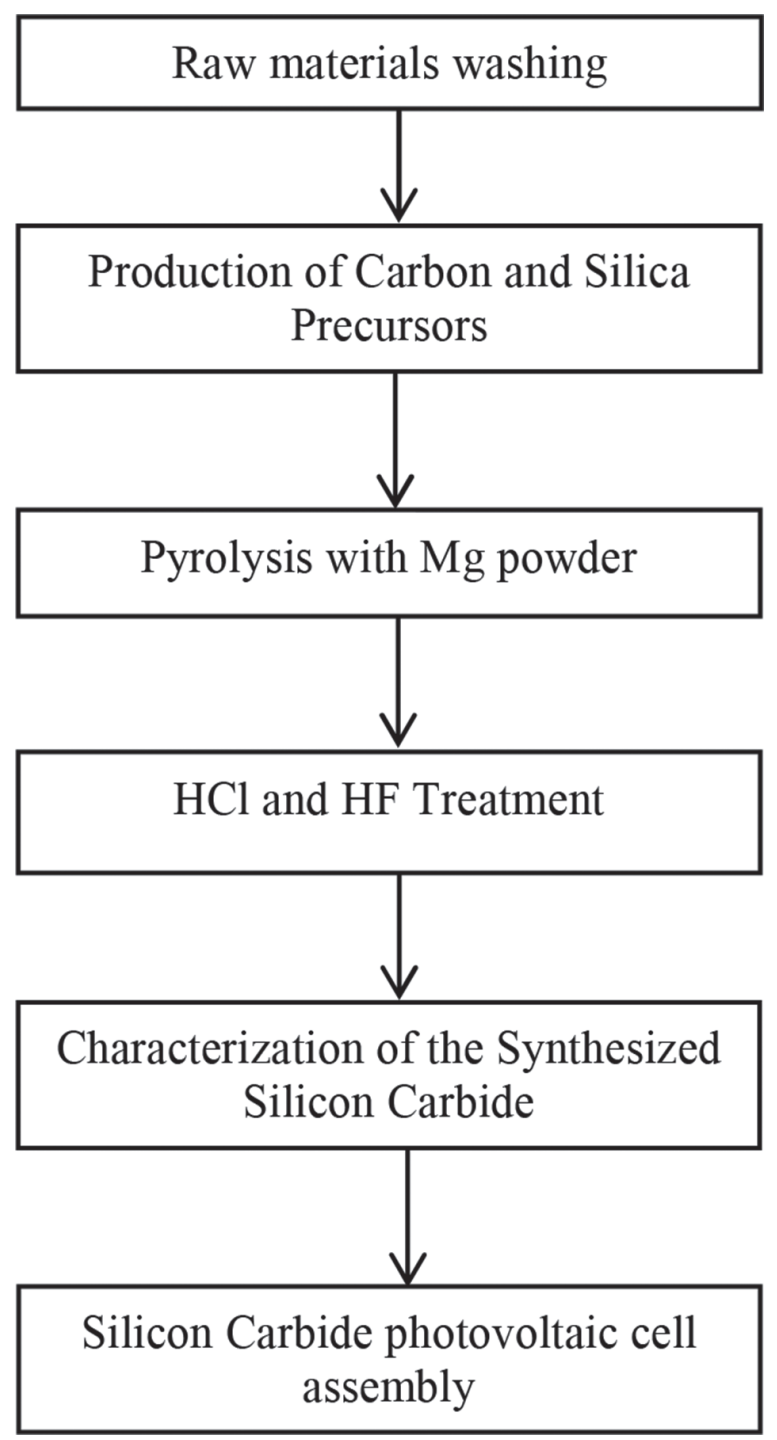

Figure 1: Flowchart from synthesis of silicon carbide ( $\mathrm{SiC}$ ) to production of a $\mathrm{SiC}$ photovoltaic cell.

$600{ }^{\circ} \mathrm{C}$ for $8 \mathrm{~h}$. The sample was reheated to $500{ }^{\circ} \mathrm{C}$ after cooling at room temperature for 30 min. The resulting solid was acid-leached to $5 \mathrm{M} \mathrm{HCl}$, and the solution was left to stand for $1 \mathrm{~h}$. The solution was filtered, and the solid was washed repeatedly with deionized water and oven-dried overnight at $100{ }^{\circ} \mathrm{C}$ to obtain $\mathrm{SiC}$ (Fig. 3).

\subsection{Synthesis of p-doped $\mathrm{SiC}$}

Approximately $0.01 \mathrm{~g}\left(\mathrm{~T}_{1}\right), 0.015 \mathrm{~g}\left(\mathrm{~T}_{2}\right), 0.02 \mathrm{~g}\left(\mathrm{~T}_{3}\right)$, and $0.1 \mathrm{~g}\left(\mathrm{~T}_{4}\right)$ of aluminum oxide were mixed in a $4 \mathrm{~mL}$ of deionized water and $0.1 \mathrm{~g}$ of $\mathrm{SiC}$ was added to each container at constant 


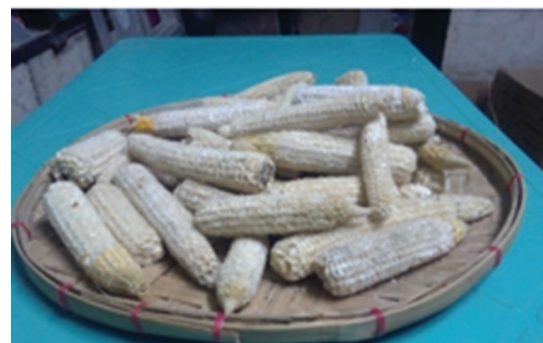

(a)

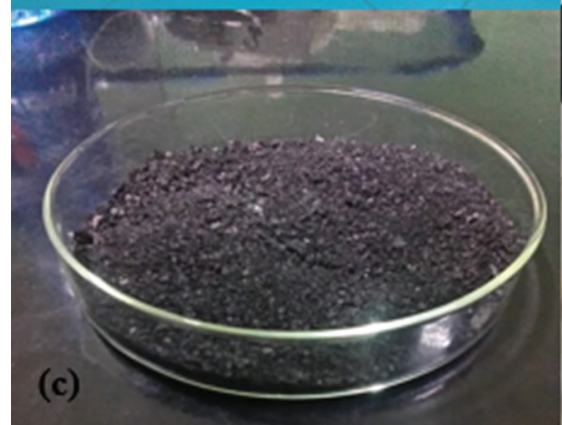

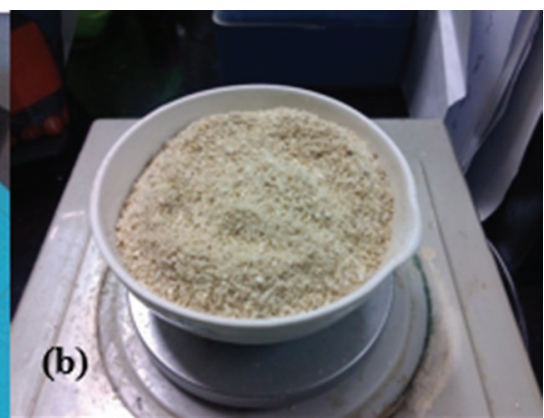

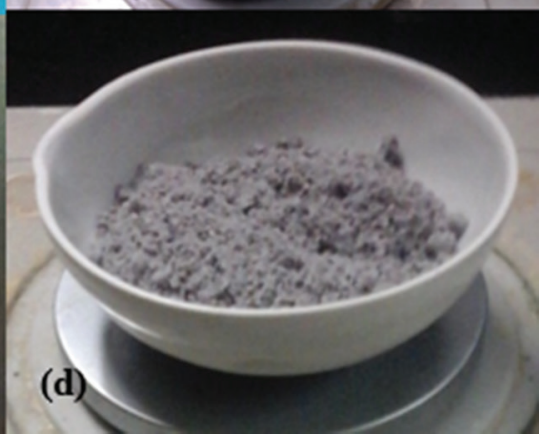

Figure 2: Macrostructural images of corn cob in different forms (a) dried-bulk corn cobs; (b) ground-corn cobs; (c) carbonized corn cob, and (d) corn cob ash powder pyrolyzed at $600 \mathrm{oC}$.
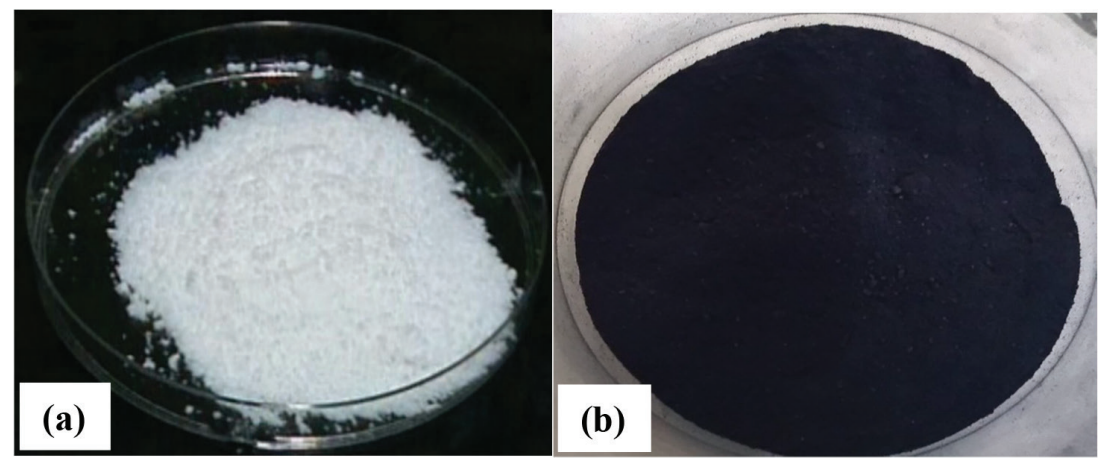

Figure 3: Macrostructural images of (a) silica from corn cob ash; and (b) activated carbon from carbonized corn cob.

stirring for $10 \mathrm{~min}$. The doping process was done via heating the solutions at $180^{\circ} \mathrm{C}$ for $12 \mathrm{~h}$ and the resulting Al-doped SiC was cooled overnight (Fig. 4).

\subsection{Characterization and performance assessment}

Voltammetric measurements were conducted to determine its potential in photovoltaic solar cell application. Cyclic voltammetry was performed to measure the band-gap, efficient charge transfer from donor to acceptor component, and effective charge transport and charge collection at the electrodes. 


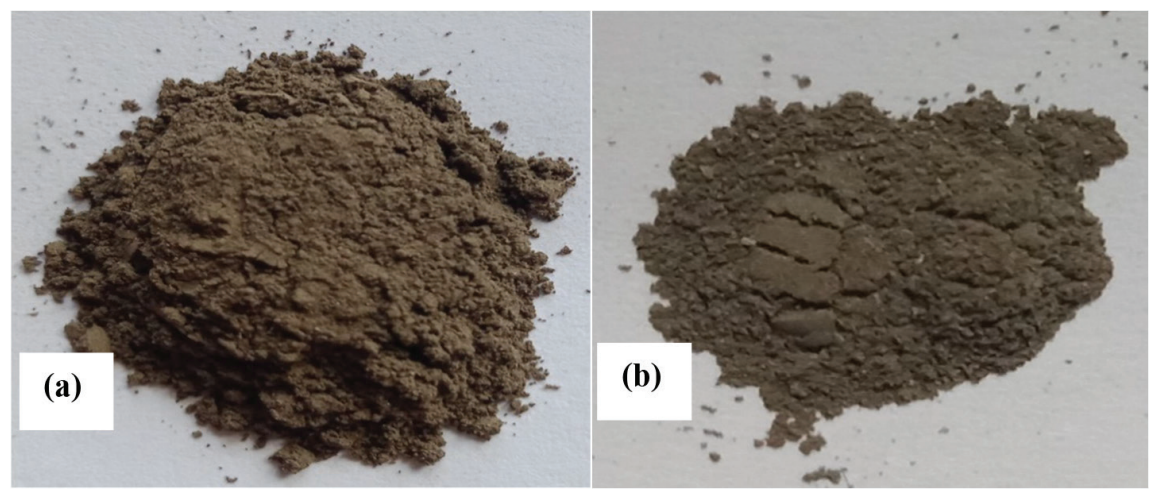

Figure 4. Macrostructural images of synthesized (a) undoped SiC; and (b) P-doped SiC.

\section{RESULTS AND DISCUSSION}

\subsection{Characterization of the synthesized $\mathrm{SiC}$}

\subsubsection{Scanning Electron Microscopy with Energy Dispersive X-ray Spectroscopy (SEM- EDX) analysis}

The SEM graph of the synthesized SiC, shown in Fig. 5, allows the determination of the surface morphology. The SEM showed large particles but irregular in shape. Figure 5 also shows the EDX spectrum of the synthesized $\mathrm{SiC}$ and confirmed the presence of Si (highest intensity), $\mathrm{C}, \mathrm{O}$, and $\mathrm{Mg}$ peaks measured between 0 and $2 \mathrm{keV}$, which revealed that the $\mathrm{SiC}$ was synthesized. Table 1 displays the mass percent of silica and carbon with a value of $60.97 \%$ (by weight) and $31.07 \%$ (by weight), respectively, indicating the predominant presence of silicon and carbon species in the sample. The presence of residues like oxygen (7.11 $\mathrm{wt} \%)$, indicated the presence of silica, and trace residual of $\mathrm{Mg}(0.85 \mathrm{wt} \%)$ was also detected because the synthesized $\mathrm{SiC}$ was only washed once with $\mathrm{HCl}$ resulted in incomplete removal of residues $\left(\mathrm{SiO}_{2}\right.$ and $\left.\mathrm{Mg}\right)$.

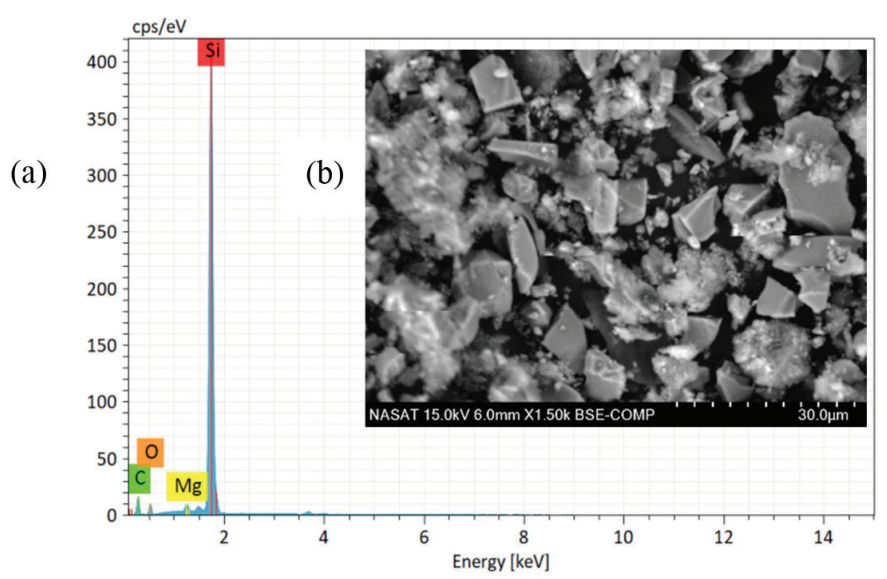

Figure 5. (a) EDX spectra of synthesized silicon carbide; (b) microstructural image of synthesized $\mathrm{SiC}$. 
Table 1: Electron dispersive X-ray spectroscopy readings of synthesized SiC.

\begin{tabular}{cccc}
\hline Element & Atomic Number & Mass Norm. $(\%)$ & Atom (\%) \\
\hline $\mathrm{Si}$ & 14 & 60.97 & 41.45 \\
$\mathrm{C}$ & 6 & 31.07 & 49.40 \\
$\mathrm{O}$ & 8 & 7.11 & 8.49 \\
$\mathrm{Mg}$ & 12 & 0.85 & 0.67 \\
\hline
\end{tabular}

3.1.2 Fourier Transform Infrared (FTIR) spectroscopy analyses

The infrared spectrum of the synthesized undoped and doped $\mathrm{SiC}$ powder is presented in Fig. 6; this allows the study of the vibration bands of $\mathrm{Si}-\mathrm{C}$ bond, as well the changes brought about by the substitution of $\mathrm{Al}_{2} \mathrm{O}_{3}$ in the silicon by SiC. Figure 6 reveals a broad band in the region of 3,000-3,700 $\mathrm{cm}^{-1}$ corresponding to the presence of hydroxyl groups that caused stretching vibration of the $\mathrm{O}-\mathrm{H}$ bond from the silanol groups. $(\mathrm{Si}-\mathrm{OH})$ due to adsorbed water molecules on the silica surface (since silica has hygroscopic properties) [3], [12]. Furthermore, the spectrum of Fig. 6 shows a band of $\mathrm{Si}-\mathrm{O}$ asymmetric stretching vibration appearing at about $1,000-1,100 \mathrm{~cm}^{-1}$ [3]. The unique peak in the $1,300-1,500 \mathrm{~cm}^{-1}$ region was the $\mathrm{C}-\mathrm{H}$ bending that might be due to carbon-hydrogen interaction between $\mathrm{SiC}$ and $\mathrm{H}_{2} \mathrm{O}$ that was adsorbed by the $\mathrm{SiC}$ powder. The peaks observed around $800-1,000 \mathrm{~cm}^{-1}$ were due to the stretching mode of $\mathrm{Si}-\mathrm{C}$ [5], which indicated that $\mathrm{SiC}$ was synthesized in the experiment.

In Fig. 7, a change in peak was observed, the spectrum displays a diminished peak in the region from 800 to $1,000 \mathrm{~cm}^{-1}$ (the $\mathrm{SiC}$ ), and an enhanced absorption peak in the $1,000-1,200$ $\mathrm{cm}^{-1}$ region. The strong absorption in the $1,000-1,200 \mathrm{~cm}^{-1}$ region corresponds to the stretching mode of $\mathrm{Al}-\mathrm{O}$ [13], which implies that the aluminum ions were integrated in the synthesized $\mathrm{SiC}$.

\subsection{Performance assessment of synthesized undoped $\mathrm{SiC}$ and p-doped $\mathrm{SiC}(\mathrm{Al}: \mathrm{SiC})$}

\subsubsection{Band-gap of synthesized and p-doped SiC}

Band-gap is the distance between the conduction band and valence band, which determines the conducting ability of a semiconductor. The synthesized SiC powders together with the p-doped $\mathrm{SiC}$ powders absorbed radiation in the visible region.

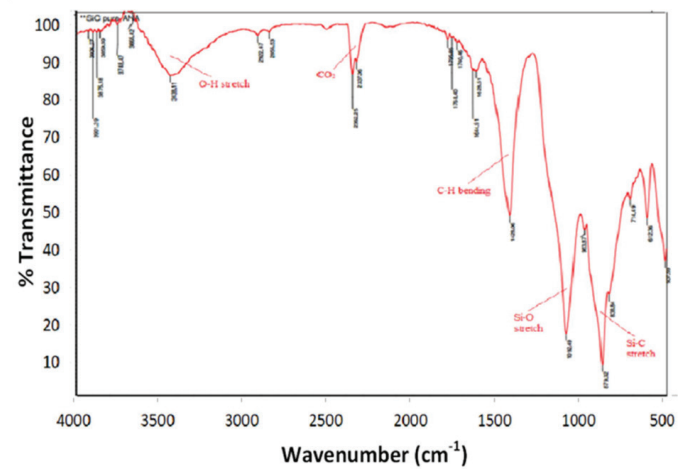

(a)

Figure 6. (a) FTIR Spectrum of synthesized $\mathrm{SiC}$ and (b) its functional groups. 
Doping the semiconductor with a metal oxide such as $\mathrm{Al}_{2} \mathrm{O}_{3}$ was intended to create local energy levels within the band-gap of the semiconductor with increase in the absorption bands in the visible region, which makes the semiconductor more efficient in absorbing energy [14]. The band-gaps of the undoped $\mathrm{SiC}$ and $\mathrm{Al}$-doped $\mathrm{SiC}$ were determined using HITACHI UH5300 UV-Visible Spectrophotometer by measuring the absorption peaks of the synthesized sample in a probable relation to the electronic transition taking place in the conduction band from valence band [14]. Table 2 shows the calculated band-gap energy of synthesized $\mathrm{SiC}$ and Al-doped SiC (or p-doped SiC).

Optical absorption analysis demonstrated that $\mathrm{p}$-doped $\mathrm{SiC}$ exhibits higher absorption in the visible region compared with undoped $\mathrm{SiC}$. This was due to the p-dopant $\left(\mathrm{Al}_{2} \mathrm{O}_{3}\right)$ that altered the lattice structure of the semiconductor $(\mathrm{SiC})$ caused by the replacement of foreign atoms that narrows the band-gap of the synthesized SiC.

Analysis of variance using STAR (Statistical Tool for Agricultural Research Ver. 7.00) showed a significant difference between undoped $\mathrm{SiC}$ and doped $\mathrm{SiC}$. The $0.01-0.02 \mathrm{~g}$ Al-doped $\mathrm{SiC}\left(\mathrm{T}_{1}-\mathrm{T}_{3}\right)$ exhibits the lowest band-gap and was found to be significantly different from undoped $\mathrm{SiC}$ and $0.1 \mathrm{~g}$ Al-doped $\mathrm{SiC}\left(\mathrm{T}_{4}\right)$. It is noted in Table 2 that the band-gap energy started to decrease from 2.07 to $1.57 \mathrm{eV}$ when $0.01 \mathrm{~g}$ of $\mathrm{Al}_{2} \mathrm{O}_{3}$ was doped in $\mathrm{SiC}$ but a significant increase in band-gap energy $(1.61 \mathrm{eV})$ was observed when $0.1 \mathrm{~g} \mathrm{Al}_{2} \mathrm{O}_{3}$ was doped in $\mathrm{SiC}$. An increase in band-gap energy after adding $0.1 \mathrm{~g} \mathrm{Al}_{2} \mathrm{O}_{3}$ may be due to the excess $\mathrm{Al}$ but it does not produce enough holes necessary for the lowering of band-gap because of the $\mathrm{Mg}$ impurity in the $\mathrm{SiC}$ produced. These synthesized Al-doped SiC $\left(\mathrm{T}_{1}-\mathrm{T}_{4}\right)$ are considered as an effective p-junction for the possible application in photovoltaic (solar) cells because they satisfied the requirement that their range lies between 1.0 and $1.7 \mathrm{eV}$ for a semiconductor in photovoltaic (solar) cell application.

\subsubsection{Conductivity of undoped $\mathrm{SiC}$ and p-doped $\mathrm{SiC}(\mathrm{Al}: \mathrm{SiC})$}

Conductivity defines a material's ability to conduct electricity. Electric current can flow easily through a material with high conductivity. A semiconductor, such as $\mathrm{SiC}$ and doped $\mathrm{SiC}$, has intermediate conductivity since it has a narrow band-gap (Table 3), and the band-gap is inversely proportional to conductivity. Table 3 shows the conductivity of undoped and doped $\mathrm{SiC}$ that confirms this relationship.

The conductivity of undoped and p-doped SiC was measured using HORIBA SZ-100. Analysis of variance using STAR showed a significant difference between undoped and doped SiC. The 0.01-0.015 g Al-doped $\mathrm{SiC}\left(\mathrm{T}_{1}-\mathrm{T}_{2}\right)$ was found to be significantly different from undoped $\mathrm{SiC}\left(\mathrm{T}_{0}\right)$ and $0.02-0.1 \mathrm{~g} \mathrm{Al}$-doped $\mathrm{SiC}\left(\mathrm{T}_{3}-\mathrm{T}_{4}\right)$. The increase of conductivity

Table 2: Band-gap energies of synthesized $\mathrm{SiC}$ and $\mathrm{p}$-doped $\mathrm{SiC}^{*}$.

\begin{tabular}{cc}
\hline Sample & Band-gap mean $(\mathbf{e V})$ \\
\hline $\operatorname{SiC}\left(\mathrm{T}_{0}\right)$ & $2.07^{\mathrm{a}} \pm 0.02$ \\
$0.01 \mathrm{~g} \mathrm{Al}$-doped $\mathrm{SiC}\left(\mathrm{T}_{1}\right)$ & $1.57^{\mathrm{b}} \pm 0.03$ \\
$0.015 \mathrm{~g} \mathrm{Al}$-doped $\mathrm{SiC}\left(\mathrm{T}_{2}\right)$ & $1.58^{\mathrm{b}} \pm 0.03$ \\
$0.02 \mathrm{~g} \mathrm{Al}$-doped $\mathrm{SiC}\left(\mathrm{T}_{3}\right)$ & $1.58^{\mathrm{b}} \pm 0.02$ \\
$0.1 \mathrm{~g} \mathrm{Al}$-doped $\mathrm{SiC}\left(\mathrm{T}_{4 \mathrm{~d}}\right)$ & $1.61^{\mathrm{c}} \pm 0.02$ \\
\hline
\end{tabular}

*Mean values with the same letter are not significantly different using STAR at 5\%. 
Table 3: Conductivity of synthesized undoped $\mathrm{SiC}$ and p-doped $\mathrm{SiC}$ particles*.

\begin{tabular}{cc}
\hline Sample & Conductivity mean $(\mathbf{m S} / \mathbf{c m})$ \\
\hline $\operatorname{SiC}\left(\mathrm{T}_{0}\right)$ & $0.061^{\mathbf{c}_{ \pm}} \pm 0.003$ \\
$0.01 \mathrm{~g} \mathrm{Al}$-doped $\mathrm{SiC}\left(\mathrm{T}_{1}\right)$ & $0.082^{\mathbf{a}} \pm 0.003$ \\
$0.015 \mathrm{~g} \mathrm{Al}$-doped $\mathrm{SiC}\left(\mathrm{T}_{2}\right)$ & $0.080^{\mathbf{a}_{ \pm} \pm 0.002}$ \\
$0.02 \mathrm{~g} \mathrm{Al}$-doped $\mathrm{SiC}\left(\mathrm{T}_{3}\right)$ & $0.071^{\mathbf{b}_{ \pm}}+0.003$ \\
$0.1 \mathrm{~g} \mathrm{Al}$-doped $\mathrm{SiC}\left(\mathrm{T}_{4}\right)$ & $0.069^{\mathbf{b}} \pm 0.002$ \\
\hline
\end{tabular}

* Means with the same letter are not significantly different using STAR at 5\%.

in the p-doped $\mathrm{SiC}$ was observed because of the sudden decrease of band-gap. This could be due to the p-dopant using $\mathrm{Al}_{2} \mathrm{O}_{3}$ that is added to semiconductor ( $\mathrm{SiC}$ ), which produced holes in the valence band. When voltage is applied, the electrons are produced from the valence band and it will jump to the conduction band to produce more electricity. Thus conductivity is enhanced due to doping. Table 3 displays the conductivity trend of the undoped $\mathrm{SiC}$ and p-doped SiC. It was observed that the $0.01-0.015 \mathrm{~g} \mathrm{Al-doped} \mathrm{SiC}(0.071-0.082 \mathrm{mS} / \mathrm{cm})$ exhibits the highest conductivity among the synthesized $\mathrm{SiC}$ since they are not significantly different [15], [16]. However, band-gap energy and conductivity in $0.02 \mathrm{~g} \mathrm{Al-doped} \mathrm{SiC}$ (refer to Table 3) are significantly different to each other because of the greater interfering effect of $\mathrm{Mg}$ in the excess $0.05 \mathrm{~g}$ of $\mathrm{Al}_{2} \mathrm{O}_{3}$ in $0.02 \mathrm{~g}$ Al-doped $\mathrm{SiC}$ that decreased its conductivity even though it has a same band-gap energy value with $0.015 \mathrm{~g} \mathrm{Al-doped} \mathrm{SiC.}$

Furthermore, when the amount of Al dopant was further increased into 0.02-0.1 g Al, the conductivity of the Al-doped $\mathrm{SiC}$ started to decrease. The decrease in the conductivity may be due to the presence of $\mathrm{Mg}$ residue in the $\mathrm{SiC}$ powder that interfered in the formation of holes brought by the addition of excess aluminum to the $\mathrm{SiC}$ material. The effect of $\mathrm{Mg}$ impurity may trap the electrons in the valence band and may inhibit the movement of electrons into the conduction band. Thus, the presence of $\mathrm{Mg}$ on the surface of $\mathrm{SiC}$ tends to agglomerate the $\mathrm{SiC}$ particle causing to decrease the conductivity of 0.02 and $0.1 \mathrm{~g} \mathrm{Al}$-doped $\mathrm{SiC}$ [17].

\section{CONCLUSIONS AND RECOMMENDATIONS}

$\mathrm{SiC}$ and $\mathrm{Al}$-doped $\mathrm{SiC}$ were successfully synthesized in this study using solid-state synthesis as supported by SEM-EDX and FTIR spectra. Nanocrystalline SiC was successfully synthesized via the solvothermal method. Compared to that produced by other methods, it is $50 \%$ less expensive than conventional silicon cells available in the market.

Performance assessment of undoped and $\mathrm{Al}$-doped $\mathrm{SiC}$ was carried out and showed that the 0.01-0.02 g Al-doped SiC has the lowest band-gap (1.57-1.58 eV) and exhibits the highest conductivity $(0.080-0.082 \mathrm{mS} / \mathrm{cm})$. Therefore, a mass ratio of $1-2: 10$ (Al:SiC) was the most efficient p-doped SiC for potential p-junction of photovoltaic (solar) cell.

Based on the findings of the study, the following recommendations are hereby advised:

1. Use of hydrofluoric acid in acid-leaching process for the complete removal of impurities such as silica and magnesium in the $\mathrm{SiC}$ for the prevention of decrease in conductivity;

2. Further characterization of p-doped SiC including: SEM to examine the surface morphology, EDS to determine the elemental composition, and X-ray diffraction (XRD) to reveal the crystallinity of the p-doped $\mathrm{SiC}$; 
3. Fabrication of synthesized p-doped $\mathrm{SiC}$ in a photovoltaic (solar) cell in order to test the actual efficiency of the p-doped $\mathrm{SiC}$ in solar absorption;

4. Test the degradation of corn cob (i.e. thermogravimetric analysis); and

5. Conduct a feasibility study on the utilization of corn cob for $\mathrm{SiC}$ synthesis.

\section{ACKNOWLEDGMENTS}

This study was supported by Physical, Inorganic, and Material Science Laboratory (PIMSlab), Department of Chemistry, Central State University, Science City of Muñoz, Nueva Ecija.

\section{REFERENCES}

[1] Teves, C., Philippine News Agency, August 1, 2019, from PH corn production up 4.66\% in 1st quarter: https://www.pna.gov.ph/articles/1035104, 2018.

[2] Chanadee, T. \& Chaivarat, S., Preparation and characterization of low cost silica powder from sweet corncobs. Journal of Material and Environmental Science, 7(7), pp. 2369-2374, 2016.

[3] Shim, J., Velmurugan, P. \& Oh, B., Extraction and physical characterization of amorphous silica made from corncob ash at variable $\mathrm{pH}$ conditions via sol gel processing. Journal of Industrial and Engineering Chemistry, 30, pp. 249-253, 2015. https://doi. org/10.1016/j.jiec.2015.05.029

[4] Abdel Rahim, M.A., Ismail, M. \& Abdel Mageed, A.M., Production of carbon and precipitated white nanosilica from rice husk ash. International Journal of Advanced Research, 3(2), pp. 491-498, 2015.

[5] Dasog, M., Smith, L., Purkait, T. \& Veinot, J., Low temperature synthesis of silicon carbide nanomaterials using solid-state method. Chemical Communications, 49, pp. 7004-7006, 2013.

[6] Negi, Y.S. \& Kumar, S., Nanoparticles synthesis from corn cob (xylan) and their potential application as colon-speficic drug carrier. Macromolecular Symposia, 320(1), pp. 75-80, 2012.

[7] Ceballos-Mendivil, I.G., Lopez, R.E., Cordova, J.C., Yescas, R.M., Zavala-Rivera, P. \& Gonzalez, J.H., Synthesis and characterization of silicon carbide in the application of high temperature solar surface receptors. Energy Procedia, 57, pp. 533-540, 2013. https://doi.org/10.1016/j.egypro.2014.10.207

[8] Mohanraj, K., Kanan, S., Barathan, S. \& Sivakumar, G., Preparation and characterization of nano $\mathrm{SiO}_{2}$ corncob ash by precipitation method. Optoelectronics and Advanced Materials-Rapid Communication, 6(3), pp. 394-397, 2012.

[9] Gonzales, A., Hernandez, A., Chaves, C., Castano, V. \& Santos, C., Novel crystalline $\mathrm{SiO}_{2}$ nanoparticles via annelids bioprocessing of agro-industrial wastes. Nanoscales Research Technology, 5(9), pp. 9654-9656, 2010. https://doi.org/10.1007/s11671-0109654-6

[10] Abderrazak, H. \& Hmida, E.S.B., Silicon Carbide: Synthesis and Properties. Properties and Applications of Silicon Carbide, Chapter 16, 2011. Doi:10.5772/15736

[11] Sharma, S., Jain, K. K. \& Sharma, A., Solar cells: in research and applications - a review. Material Sciences and Applications, 6, pp. 1145-1155, 2016. https://doi. org/10.4236/msa.2015.612113

[12] Zhang, Y., Yang, M., Zhan, G. \& Dionysiou, D., $\mathrm{HNO}_{3}$-involved one-step low temperature solvothermal synthesis of $\mathrm{N}$-doped $\mathrm{TiO}_{2}$ nanocrystals for efficient photo- 
catalytic reduction of $\mathrm{Cr}(\mathrm{VI})$ in water. Applied Catalysis B: Environmental, 142-143, pp. 249-258, 2013. https://doi.org/10.1016/j.apcatb.2013.05.023

[13] Vahur, S., Teearu, A., Peets, P., Joosu, L. \& Leito, I., ATR-FT-IR spectral collection of conservation materials in the extended region of 4000-80 cm-1. Analytical and Bioanalytical Chemistry, 408(13), pp. 3373-3379, 2016. https://doi.org/10.1007/s00216016-9411-5

[14] Nie, S. \& Smith, A., Semiconductor nanocrystals: Structure, properties, and band-gap engineering. Accounts of Chemical Research, 43(2), pp. 190-200, 2019. https://doi. org/10.1021/ar9001069

[15] Okoronkwo, E.A., Imoisili, P.E. \& Olusunle, S.O.O., Extraction and characterization of Amorphous Silica from Corncob Ash by Sol-Gel Method. Chemistry and Material Research, 3(4), pp. 68-72, 2013.

[16] Gopal, V.R.V. \& Kamila, S., Effect of temperature on the morphology of ZnOnanoparticles: a comparative study. Applied Nanoscience, 7, pp. 75-82, 2017. https://doi.org/ 10.1007/s13204-017-0553-3

[17] Hirayama, N., Iida, T., Sakomoto, M., Nishio, K. \& Hamada, N., Substitutional and interstitial impuriry p-type doping of thermoelectric $\mathrm{Mg} 2 \mathrm{Si}$ : a theoretical study. Science and Technology of Advanced Materials, 19, pp. 160-172, 2019. https://doi.org/10.108 0/14686996.2019.1580537 